\title{
THE VULNERABILITY OF CORRESPONDENT BANKING ON MONEY LAUNDERING
}

\author{
By: Sigit Handoyo,,SE.,M.Bus"
}

\section{ABSTRACT}

Bank has important role in process of converting illicit money to be legal proceeds. Once opportunity appears, money launderer will take advantage of that situation. Generally, banks which have poor anti-money laundering control become the main priority for offenders to process laundering their illicit money. These typical banks are usually high risk engaged in criminal behaviour, because they do not know whether or not their clients are engaged in money laundering activities. Offenders in other countries also use those banks as correspondent banks where they may use in transferring money. Some preventive actions have been conducted by some banks of some countries to detect the patterns of money laundering to have good anti-money laundering control, such as the US and Australia by applying advances technologies, such as data mining technologies in identifying the patterns. However, applying those technologies is not enough for preventing money laundering activities due to the inherent weaknesses on it. Thus by having good anti-money laundering control is a compulsory for banking.

Key words: Illicit money, proceeds of crime, anti-money laundering control, correspondent banking, money laundering, data mining technology

\section{A. INTRODUCTION}

Many types of crime stipulated by both individuals as well as corporations within the territory across the borders are common in this era. Comuption, bribery, smuggling, workers smuggling, smuggling of immigrant, banking; illegal trafficking in drugs, and various white collar crime are the example of these kinds of crimes. The proceeds from these crimes are illegal money that needs to be converted into legal money. Advance in technology may ease all activities in crimes and is being taken advantage in transferring proceeds easily and quickly such as financial information, technology and telecommunication (UN, 2006).

It is estimated that US\$1 trillion laundered annually worldwide (Scott, 1995). As a consequences, banking institution required to complete currencies transaction report (CTR) and suspicious activities report (SAR) for all deposits, withdrawals, and currency exchanges over US $\$ 10,000$. However, another.problem rises relating to handle large amount of those reports. For description, at federal level in US more than 7 million CTRs each year were sent. In addition

*) Sigit Handoyo, SE.,M.Bus adalah Dosen Fakultas Ekonomi Universitas Islam Indonesia. 
approximately 40,000 wire transfers each day in one New York bank (Abadinsky, 1997), and advances in banking technology ease to transfer money by wire transfer. It is needed only 45 seconds to launder by wire tranisfer and it took the police officers 18 months to investigate the case. In 2004 there are 214,797 categories are suspected violations (FinCEN Release, 2004). Thus a prevention system in money laundering activities should be had by banking system. Efforts have been carrying out by banking system in many countries to prevent, identify, detect and investigate the patterns or the activities relating money laundering. Recently, many countries rely on data mining technology to assist in finding the money laundering patterns that has been giving much contributions for many countries which seriously against money laundering activities. However, besides the advances of new technologies should be relied on, other aspect such as regulation should also be another important priorities, particularly relate to bank operations.

\section{B. NATURE OF MONEY LAUNDERING}

Money Laundering is the effort to covert illegal proceeds intolegal money by laundering in such way through financial system such as banks. Basically money laundering involves 3 phases: placement, layering and integration (Madinger and Zalopany, 1999). Firstly, placement, namely attempting to place cash derived from criminal acts into the financial system or attempting to place cheque, bank draft, deposit certificate and other into the financial system, especially the banking system.

Secondly, layering or transfer namely attempting to transfer assets derived from criminal acts (dirty money) placed successfully at one Provider of Financial Services (especially banks) as proceeds from attempted placement to another Provider of Financial Services. By conducting layering, it is difficult for law enforcement agencies to trace the origins of such assets.

Thirdly, integration or using assets namely attempting to use assets derived from criminal acts brought into the financial system successfully through placement or transfer as if it were clean money, for clean business purposes or for re-financing criminal activities.

\section{THE, VULNERABILITY OF CORRESPONDENT BANKING TO MONEY LAUNDERING}

Banks have important role in money laundering activities. Once banks have poor anti-money laundering control, those banks have significant possibility to be engaged in money laundering because some of their clients who are engaged in criminal behavior will take the advantage of the opportunity. These banks become correspondent banking for the foreign banks which typically highly risk bank in money laundering that are used by criminal to transfer their illicit money to open account at correspondent banks. Due to the lack of resources and staff, those banks tend to use their correspondent banks to carry out the operation of their banks. 
There are 3 kinds of high risk potential banks in money laundering activities: shell Banks, offshore banks, and licensed and regulated banks (Minority Staff of the Permanent Subcommittee on Investigations. 2001). Shell banks are high risk banks principally because they are so difficult to monitor and operate with great secrecy. Offshore banks are banks which have licenses which bar them from transacting banking activities with citizens of their own licensing jurisdiction or bar them from transacting business using the local currency of the licensing jurisdiction.

Once a correspondent account is open in a country, not only the foreign banks but also their clients can transact business through the banks in that country. As a consequence, those correspondents bank become a gateway for money launderers to carry out their actions in financial system. For example, this case occurs in the US. High risk foreign banks have been able to open correspondent accounts at US banks and conduct their operations through their US accounts, because, in many cases, US banks fail to adequately screen and monitor foreign banks as clients (Minority Staff of the Permanent Subcommittee on Investigations. 2001).

\section{REGULATION}

Regulation relates to correspondent banking is on 40 recommendations FATF, recommendation number 7 which financial institution should: gather sufficient information about a respondent institution to understand fully the nature of the respondent's business, access the respondent institution's anti-money laundering and terrorist, obtain approval from senior management before stabling new correspondent relationship, document the respective responsibilities of each institution (FATF, 2003). That recommendation shows that it is necessary for financial institutions to enquiry the risk status of correspondent banks relate to money laundering and terrorism which they are going to have relationship: Exposure draft nule of Australia Anti-Money laundering and Counter-Terrorism Financing Bill 2006 (AML/CTF Bill) chapter 7 states that a financial institution must be assessed before entering a correspondent relationship with another financial institution and provide due diligence enquiries according to the correspondent banking risk. Thus by understanding the condition of financial institutions which will be correspondent banks, a financial institution may prevent the operation of money laundering activities by offenders. Another regulation that has relationship with this term is that on recommendation $35,36,37$, 38,39 and 40 of FATF about international co-operation. All countries are expected to co-operate in mutual legal assistance, particularly in simplifying ex- . tradition, in relation to money laụndering and terrorism.

\section{E. DE-TECTION}

Detection on the pattern of the activities of money laundering activities has beer developed since several decades. Some techniques are being employed to assist in investigation that activity. There are 2 kinds of techniques: traditional technique and new technique using data mining technology. 
Sigit Handoyo: The Vulnerability of Correspondent Banking on Money Laundering

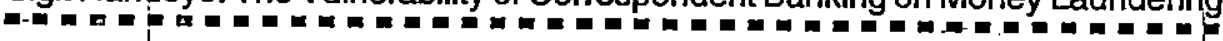

Traditional investigative techniques have some weaknesses that emergence need new approach in terms of time consuming in identification and man-hours consuming. In this approach, identification of money laundering patterns takes a long time because there are difficulties in both processing large volume of data sets and accessing of expert data sets by non federal law enforcement agencies.

Advances technologies have been developing law enforcement to identify and to detect the patterns of fraud including money laundering activities in several years. Recently, it is introduced technologies to detect those patterns in 1990s, named data mining technologies or new technique.

Data mining technologies are new innovative approaches that utilized to investigate the patterns of money laundering. There are 2 tools introduced in data mining technology, which are Financial Crimes Enforcement Network Al Systems (FAIS) and Origami software package. Both of them are used to assist in identifying money laundering activities and patterns. FAIS needs report of the large transaction (CTRs and SARs) to evaluate the pattems of money laundering.

In Origami method, investigation is conducted by analysis network to reveal illegal activities through telephone line. Some of the most popular tools in data mining application rely on statistical and artificial intelligence (AI) techniques, such as linear regression, logistic regression, cluster analysis, inductive algorithms, neural networks, fuzzy logic, and genetic algorithms.

Linear regression model, the most basic approach in data mining, is designed by defining a dependent variable (output) and a number of independent variables (inputs). The result of a linear regression model is an equation of a line that best fits the data set, which can be used for prediction process.

Logistic regression is very popular means of data mining because it can solve problems involving categorical variables. While, cluster analysis can be used to mine large data sets for investigative lead generation and to isolate statistically significant relationships between suspect networks, modes of conveyance and locations from which drugs and illegal proceeds are exchanged. Inductive algorithms can assist national and international investigators uncover money laundering patterns by generating decision trees based on historical outcomes.

Neural networks are the technique utilizing digital computers to mimic the operation of the learning structure that exist the human brain. This technique also can be used with continuous or categorical variables and non-linear and collinear data.

Fuzzy logic is the technique utilizing a theory that allows incomplete information to be processed and conclusions derived. While, genetic algorithms are the technique used to tracked money laundering operations and to solve a variety of optimal tasks.

F. : BENEFIT ÁND WEAKNESSES OF DATA MINING TECHNOLOGGY. tion.

Besides their benefits, using data mining technologies have some limita- 
There are 3 benefits in utilize data mining technologies: efficient in time consuming, reducing problems in financial investigations, and the identification of more leads, accurate and timely leads. The use of data mining technologies also has several limitations: lack of trained-analysts to utilize these techniques, difficulty in access to the data sets from the expert systems, difficulty in identifying money laundering if the offenders have bias information, and difficulty in the culture of law enforcement.

\section{G CONCLUSION}

Activity of correspondent banking is only one of many activities which has vulnerability to money laundering. Since this activity involves other banks in other countries which are possibility high risk engaged clients involved in transferring illicit money, this activity should be another priority in combating money launder-i ing besides development in data mining technologies. Because of the limitation in data mining technologies, efforts against of money laundering would be better to engage the regulation such as FATF 40 recommendations and conduct international co-operation especially relates to anti-money laundering control.

\section{BIBLIOGRAPHY}

Abadinsky, H. 1997. Organized crime (6 $6^{\text {th }}$ ed.) Belmont, CA:Wadsworth

AMLCTFRules. 2006. www.austrac.gov:au/am/pdfs/summany of aml rules.pdf

AUSTRAC. 2004. Annual Report 2004-2005. (accessed October, 2006, from ProQuest: Academic Research Library database).

FATF. Money Laundering. 2003. www.fatf-gafi.org/document

FinCEN. 2004. Release 2004 SARS Totals.(accessed October 13, 2006, from ProQuest: Criminal Justice Periodical database):

Madinger, J. and Zalopany, S. 1999. Money Laundering: A guide for criminal investigator. New.York: CRC Press.

Minority Staff of the Permanent Subcommitee on Investigations. 2001. Report on Correspondent Banking: A Gateway for Money Laundering. www.senate.gov/ gov affairs/psi finalreport.pdf

Scott, D. 1995, May. Money laundering and intemational efforts to fight it. Public Policy for the Private Sector, 48:1-6.

Standberg, K. 1997. Money Laundering. Law Enforcement Technology. 4:28-33

UN. 2006. Global Programme Against Money Laundering. www.unodc.org/unodd/ en/money_laundering.html

Watkins et. al. 2003. Tracking Dirty Proceeds: Exploring Data Mining - Technologies As Tools To Investigate Money Laundering. Journal of Policing Practice and Research. 4(2);163-178 